\title{
First Report on Isolation and Characterization of Leishmania major from Meriones hurrianae (Rodentia: Gerbillidae) of A Rural Cutaneous leishmaniasis Focus in South-Eastern Iran
}

\author{
Hamid Kassiri ${ }^{1,}$, Saied Reza Naddaf ${ }^{2}$, Ezat-Aldin Javadian ${ }^{3}$, Mehdi Mohebali ${ }^{4}$ \\ ${ }_{2}^{1}$ Department of Medical Entomology and Vector Control, School of Health, Ahvaz Jundishapur University of Medical Sciences, Ahvaz, IR Iran \\ ${ }_{3}^{2}$ Department of Parasitology, Pasteur Institute of Iran, Tehran, IR Iran \\ 3 Department of Medical Entomology and Vector Control, School of Public Health, Tehran University of Medical Sciences, Tehran, IR Iran \\ 4 Department of Medical Parasitology, School of Public Health, Tehran University of Medical Sciences, Tehran, IR Iran \\ *Corresponding author: Hamid Kassiri, Corresponding author: Hamid kassiri, School of Health, Ahvaz Jundishapur University of Medical Sciences, Ahvaz, IR Iran; Tel:+98-6113738269, \\ Fax:+98-6113738282, E-mail: Hamid.Kassiri@yahoo.com.
}

Received: Jun 25, 2012; Revised: May 29, 2013; Accepted: Jun 11, 2013

\begin{abstract}
Background: Zoonotic Cutaneous Leishmaniasis (ZCL) is an endemic health problem in many rural areas of Iran, with doubled number of incidences over the last decade. Different species of rodents serve as natural reservoir host for ZCL. The disease is considered as a major health problem in rural areas of Mirjaveh, Chabahar, and Konarak Counties of Sistan va Baluchistan Province.

Objectives: This study describes the identity of Leishmania species, isolated from Meriones hurrianae from Chabahar County using RAPDPCR methodology.

Materials and Methods: Rodents were entrapped by live traps baited with roasted walnut, tomato, and cucumber during spring and summer. All rodents were identified based on external features including fur color, ears characteristics, tail length, hind feet, body measurements, and internal features of teeth and cranium. Giemsa-stained impressions from rodents' ears were examined for amastigotes microscopically. The samples from infected rodents were cultured in NNN+LIT medium and then the harvested parasites at the stationary phase were subjected to DNA extraction followed by amplification with RAPD-PCR.

Results: All the 28 entrapped animals were identified as M. hurrianae. Five animals showed to harbor Leishmania parasite by microscopy. Leishmania DNA isolated from five M. hurrianae produced distinctive bands of L. major with four primers. However, the products that were amplified with primers AB1-07, 327, and 329 were stable and reproducible. This is the first report on the isolation and identification of $L$. major from M. hurrianae from Iran.

Conclusions: Regarding infection rate of $17.8 \%$, M. hurrianae seems to play the major role in the maintenance and transmission of disease to humans in this area.
\end{abstract}

Keywords: Meriones hurrianae; Leishmania major; Molecular Characterization; RAPD-PCR; Reservoir Host; Iran

\section{Background}

Leishmaniases, most zoonotic, are complex worldwide diseases caused by more than 20 species of Leishmania belonging to the family Trypanosomatidae (order Kinetoplastida). Leishmania parasites are transmitted via the infective bites of about 30 different species of sand flies (subfamily Phlebotominae) $(1,2)$.

Leishmaniasis is prevalent in many tropical and subtropical areas covering about 88 countries with approximately 350 million people at risk of acquiring the infection (3). There are four main forms of leishmaniasis: Visceral Leishmaniasis (VL), Mucocutaneous Leishmaniasis (MCL), Diffuse Cutaneous Leishmaniasis (DCL), and Cutaneous Leishmaniasis (CL) (3). CL is the most common form of disease; Patient generally presents with one or several ulcer (s) or nodule (s) in the skin. Over $90 \%$ of cases of CL have been reported in Afghanistan, Iran, Iraq, Saudi Arabia, Syria, Algeria, Brazil, and Peru (4).

Three species of Leishmania parasites are etiological agents of CL in the old world: L. major, L. tropica and L. aethiopica (5). L. major and L. tropica are the causing agents for Zoonotic Cutaneous Leishmaniasis (ZCL) and Anthroponotic Cutaneous Leishmaniasis (ACL) are prevalent in Iran with infection prevalence ranging from $1.8 \%$ to $37.9 \%$ in different Provinces (6).

ZCL is endemic in many rural districts of Iran affecting 17 out of 31 Provinces. Various species of rodents (family: Gerbillidae) have been incriminated as natural reservoir hosts of ZCL in Iran. Rhombomys opimus is known as the primary reservoir in central, north, and north eastern Iran $(7,8)$. Meriones libycus plays the secondary role as

Implication for health policy/practice/research/medical education:

Identification of definitive reservoir hosts of ZCL in different zoogeographical zones is a prerequisite key for adopting control measure and management of disease. Hence, this result will help health authorities for planning ZCL reservoir control activities.

Copyright (C) 2013, Iranian Red Crescent Medical Journal; Licensee KowsarKowsar Ltd. This is an Open Access article distributed under the terms of the Creative Commons Attribution License (http://creativecommons.org/licenses/by/3.0), which permits unrestricted use, distribution, and reproduction in any medium, provided the original work is properly cited. 
reservoir host alongside R. opimus in central Iran (9) and is also known as primary host in Arsanjan, Neiriz, Marvdasht counties (Fars Province), Ardestan County (Isfahan Province) and Qom County (Qom Province) (10-13). In Natanz County (Isfahan Province), besides the two above mentioned species, Leishmania infection has been detected in Meriones persicus. In Damghan area (Semnan Province), north Iran, Nesokia indica, M. libycus, and R. opimus are known as main reservoir hosts $(14,15)$. In south, west, and south western Iran Tatera indica is the primary host along with $N$. indica and $M$. libycus as the secondary hosts $(16,17)$. In southeastern Iran M. hurrianae and T. indica are primary and secondary reservoir hosts for ZCL, respectively (18). There are also records for infection of Gerbillus ssp. and Rattus norvegicus to L. major in Fars Province $(19,20)$, and Gerbillus nanus in Jask County (Hormozgan Province) (21). One of the major problems for control of ZCL is lack of knowledge about the nature of Leishmania parasites in reservoir hosts population.

\section{Objectives}

This study describes isolation of Leishmania parasite from M. hurrianae in rural areas of Chabahar County, Sistan va Baluchistan Province followed by identification of the species using DNA analysis.

\section{Materials and Methods}

\subsection{Study Area}

Chabahar County is located on the shore of Oman Sea littoral in southeastern province of Sistan va Baluchistan, Iran. This County is a low landing area; with geographical coordinates of $25^{\circ} 17^{\prime}$ North, $60^{\circ} 38^{\prime}$ East. The climate of this area is classified as very warm desert due to its low annual precipitation. The average annual temperature and humidity are $36.4^{\circ} \mathrm{C}$ and $75.9 \%$, respectively. Chabahar County covers an area of $24,729 \mathrm{Km}^{2}$, with 230,000 residents. The majority of the county's inhabitants are ethnic Baluch, speaking the Baluchi language. This descriptive cross-sectional study was carried out in 1997 in 3 villages (Negor , Pollan and Noubandian) of Chabahar County, Dashtiyari Division of Chabahar, where CL emerged as an endemic disease.

\subsection{Sample Collection}

Three trained persons with the same educational and professional levels were hired for rodents catching all over the study period. The ethical principles of this research were investigated and discussed in research committee of medical entomology department and necessary modifications made, faced to be approved. The sample size was selected at the minimum accepted levels because of the ethical aspects related to the animal rights. Before killing the rodents for reducing their painful feeling, we used Ether or Chloroforme as an anesthetized agent. The sample size was chosen using below Formula :

$$
n=\frac{1.96^{2} \times 0.05(0.95)}{0.0065}=28
$$

Formula

Also, expected power was calculated $75 \%$. Based on our research design all sampling were done using simple randomized approach. SPSS 16 and MINITAB 14 softwares were applied for statistical analysis of data.

Rodents were entrapped by live traps baited with roasted walnut, tomato, and cucumber during spring and summer. The traps were placed at sunset and collected at dawn. All rodents were identified based on external features including fur color, ears characteristics, tail length, hind feet, body measurements, and internal features of teeth and cranium.

In this research, infection of the rodents observed through microscopic and PCR (Polymerase Chain Reaction) method. Impression smears were taken from rodent's ears, stained with Giemsa, and examined microscopically for amastigotes. The samples from infected rodents were cultured in Novy-MacNeal-Nicolle (NNN) medium, liver infusion broth tryptose (LIT) and then checked twice a week for promastigotes. The positive cultures were then transferred to RPMI 1640 medium supplemented with $10 \%$ heat inactivated fetal calf serum. The parasites were harvested at the stationary phase and kept at $-20^{\circ} \mathrm{C}$ until used.

\subsection{DNA Extraction}

The harvested parasites were washed in cold sterile PBS ( $\mathrm{pH}$ 7.2) several times. The recovered pellet was re-suspended in $300 \mu \mathrm{L}$ cell lysis buffer $(50 \mathrm{mM} \mathrm{NaCl}, 50 \mathrm{mM}$ EDTA, $1 \%$ SDS, and $50 \mathrm{mM}$ Tris-HCl, pH 8.0) with $20 \mu \mathrm{L}$ of $20 \mathrm{mg} / \mathrm{mL}$ proteinase $\mathrm{K}$ and incubated at $55^{\circ} \mathrm{C}$ overnight. DNA was extracted from lysate with phenol/chloroform followed by ethanol precipitation. The DNA was re-suspended in distilled water and working solutions were adjusted to $5 \mathrm{ng} / \mu \mathrm{L}$ in distilled water.

\subsection{RAPD-PCR Analysis}

The RARD-PCR assays were performed as outlined by others $(14,22)$. Each $25 \mu \mathrm{L}$ reaction contained $10 \mathrm{mM}$ Tris$\mathrm{HCl}, \mathrm{pH} 8.3,50 \mathrm{mM} \mathrm{KCl} 2,2 \mathrm{mM} \mathrm{MgCl} 2,200 \mu \mathrm{M}$ of each dNTP, 50 pmol of one of the primers (Table 1), 1 unit of Taq DNA polymerase, and 10 ng of DNA. Reactions were overlaid with $25 \mu \mathrm{L}$ of mineral oil and amplified with a 
thermocycler programed for one cycle at $94^{\circ} \mathrm{C}$ for $5 \mathrm{~min}$ followed by 45 cycles of denaturation at $94^{\circ} \mathrm{C}$ for $1 \mathrm{~min}$, annealing at $37^{\circ} \mathrm{C}$ to $38^{\circ} \mathrm{C}$ for $1 \mathrm{~min}$, and extension at $72^{\circ} \mathrm{C}$ for $2 \mathrm{~min}$ and a final extension step at $72^{\circ} \mathrm{C}$ for $5 \mathrm{~min}$. A negative control, containing all components except DNA, was included in all assays. Amounts of 8-10 $\mu \mathrm{l}$ of amplicons were run alongside a DNA size marker (Roche, Germany) on a Electrophoresis (1.2\% agarose gel containing ethidium bromide) and visualized on a UVTransilluminator. Resulting bands were examined and photographed.

\begin{tabular}{llll}
\hline \multicolumn{4}{l}{ Table 1. The Primers Used in RAPD-PCR Analysis } \\
\hline No. & Code & Sequence & \% GC \\
\hline $\mathbf{1}$ & AB1-07 & GGT GAC GCA G & 70 \\
$\mathbf{2}$ & 327 & ATA CGG CGT C & 60 \\
$\mathbf{3}$ & 329 & GCG AAC CTC C & 70 \\
$\mathbf{4}$ & 335 & TGG ACC ACC C & 70
\end{tabular}

\section{Resutls}

A total of 28 rodents were collected with live traps from three villages. All the animals were identified as M. hurrianae (Figure 1 and Figure 2). Microscopical examination of Giemsa- stained impression smears from rodents ears showed that five out of 28 animals were infected with amastigotes. The parasites from 5 animals were grown successfully in culture medium. DNA amplification with RAPD-PCR of DNA from 5 isolates yielded distinctive bands that were characteristic of L. major with four primers, but the products that were amplified with primers AB1-07, 327, and 329 were stable and reproducible in all assays (Figure 3, Figure 4 and Figure 5). This is the first report on the isolation and identification of L. major from this rodent species in Iran.

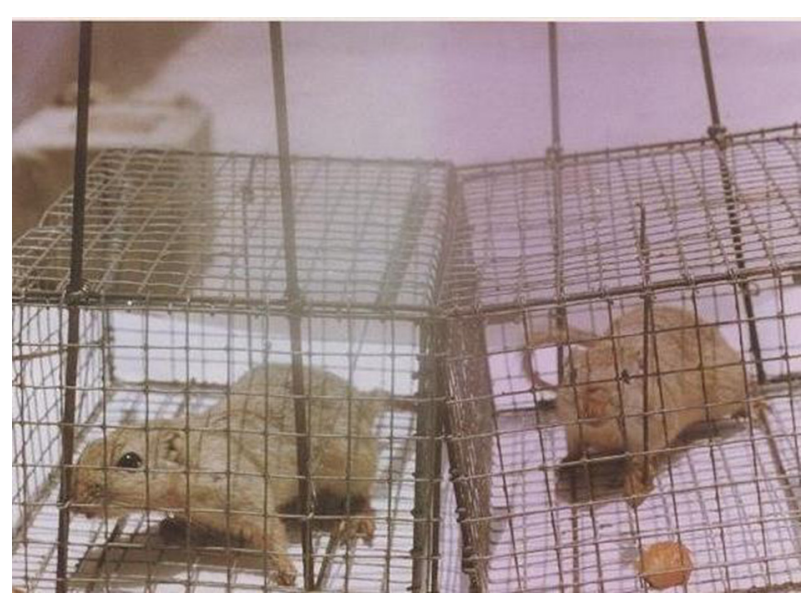

Figure 1. Meriones hurrianae Entrapped in Chabahar County, Sistan va Baluchistan Province, Iran

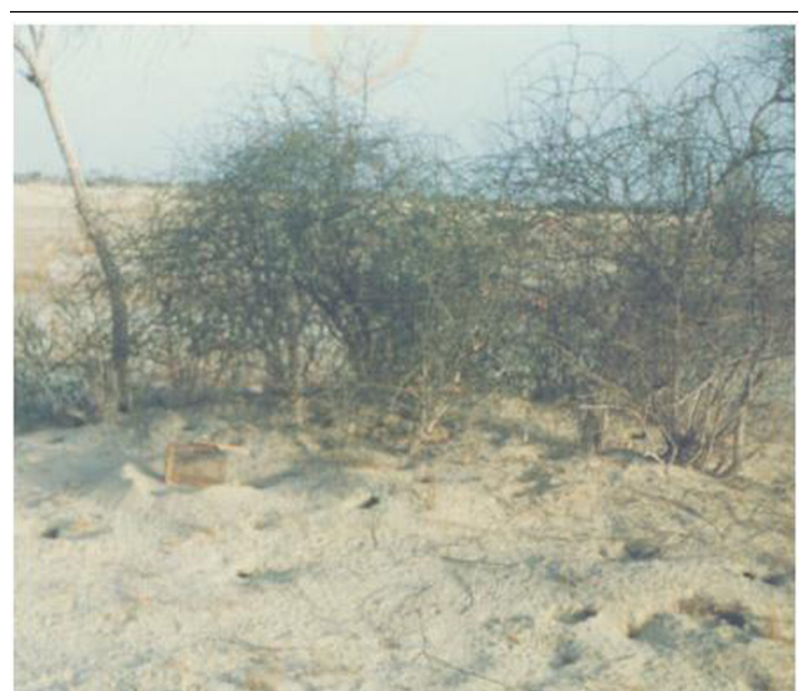

Figure 2. Typical Rodent Burrows of Meriones hurrianae, Chabahar County, Sistan va Baluchistan Province, Iran

Figure 3. Electrophoresis of Gene Fragments Amplified With RAPD-PCR Using the Primer 329

$\begin{array}{lllllllllll}1 & 2 & 3 & 4 & 5 & 6 & 7 & 8 & 9 & 10 & \mathrm{VI}\end{array}$

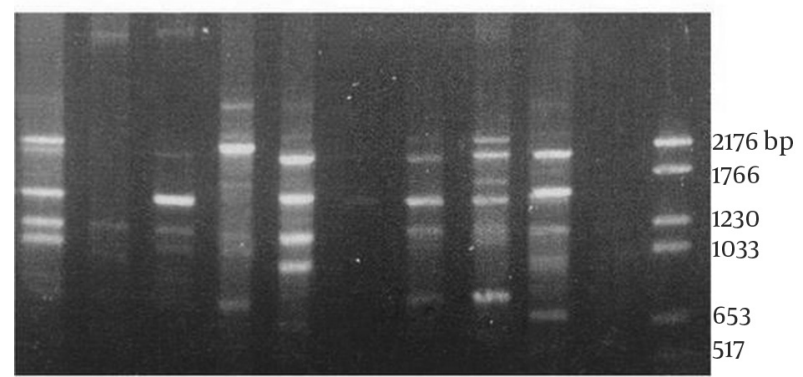

Lanes 1, 4, 6, and 8 different strains of L. major, lane 2 L. donovani; 5 and 9 different strains of L. tropica; lane 3, the strain originated from Merhurrianae (This study); lane10, control; lane 11, DNA size marker VI (Roche, Germany)

Figure 4. Electrophoresis of Gene Fragments Amplified with RAPD-PCR Using the Primer 327

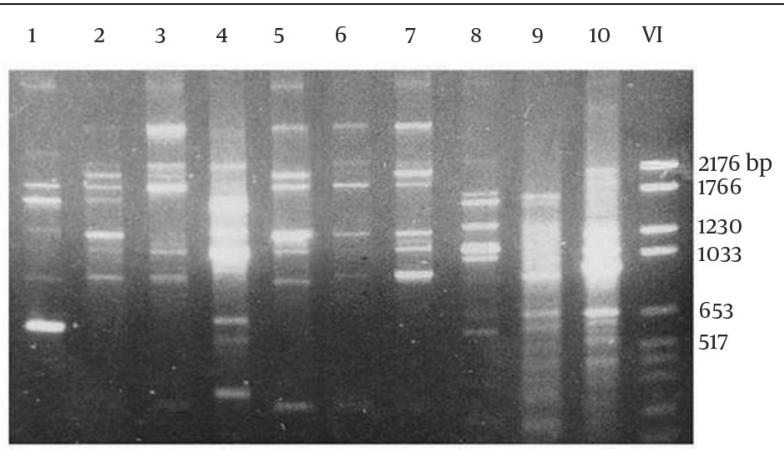

Lanes 1, L. infantum; Lanes 2, 5, 6 and 7 different strains of L. major, lanes 4, 8,9 , and 10 different strains of L. tropica; lane 3 , the strain originated from M. hurrianae (This study); lane 11, DNA size marker VI (Roche, Germany) 
Figure 5. Electrophoresis of Gene Fragments Amplified with RAPD-PCR Using the Primer AB1-07

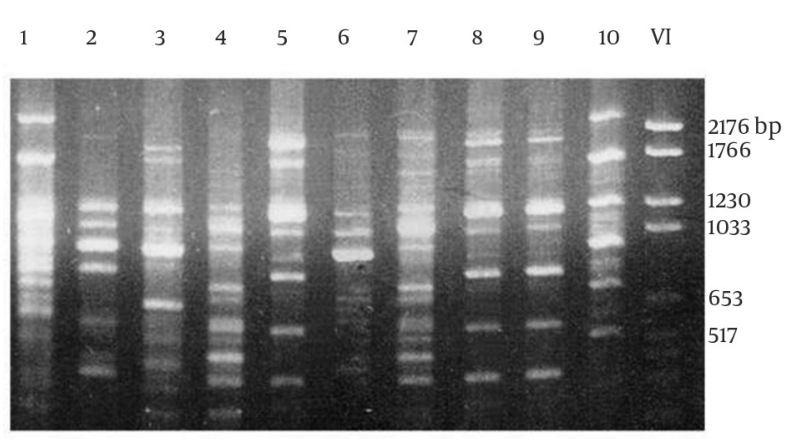

Lanes 1 and 10 L. infantum; Lanes 2, 3, and 6 different strains of L. major; lanes $4,7,8$, and 9 different strains of $L$. tropica; lane 5, the strain originated from M. hurrianae (This study); lane 11, DNA size marker VI (Roche, Germany)

\section{Discussion}

WHO (World Health Organizaton) introduces the leishmaniasis as one of the six important worldwide infectious diseases. So, doing researches on leishmaniasis and focusing on its several aspects is highly recommended. Movement of immune people to endemic regions, presence of people with lesion, increasing population, existence of rodent burrows and presence of infected sand flies have made the most suitable conditions for disease transmission, in the Chabahar County.

Leishmania major, the etiological agent of ZCL, is the disease of rodents in arid and savannahs from the old World. In Iran, different species of rodents belonging to family Gerbillidae have been incriminated as reservoir hosts of this parasite and new species are increasingly added to the list. Zoonotic Cutaneous leishmaniasis has also been reported during recent decades in rural areas of Chabahar County, Sistan va Baluchistan Province, southeast Iran, bordering with Pakistan.

The most prevalent sand fly species in this area, Phlebotomus papatasi and P. salehi, were found to be infected with $L$. major with RAPD-PCR assay (23). The most prevalent rodent species in the area, $M$. hurrianae, has already been identified as a reservoir host of L. major in India (5). This species has been recorded in the Thar Desert of India, Iran, and Pakistan. In Pakistan it has been seen in Punjab, Sindh, Baluchistan and north west frontier Province. It is questionably present in Afghanistan at Kelat-i-Ghilzai between Ghazni and Kandahar (24).

In this study, Leishmania parasites were isolated from M. hurrianae in Chabahar County and were identified as L. major with RAPD-PCR assey. Regarding infection rate of about $17.8 \%$ in M. hurrianae, this species can be considered as the main reservoir host of ZCL and the principle source of human infection in this area. With concern to the results of this research, it is obvious that the ZCL foci in Chabahar County exist and this form is dominant. As L. major (dominant species), is a zoonotic parasite, then we should have special concern related to the rural areas immigrants and also rodent control in these regions. By this respect, the PCR molecular technique is a highly reliable procedure for diagnosis of Leishmania specie. In PCR method, as DNA of Leishmania species is examined, therefore its sensitivity and specificity are so high.

\section{Acknowledgements}

We gratefully acknowledge our colleagues at Iranshahr Institute of Health Research, Tehran University of Medical Sciences, and Chabahar Health Center for assisting us throughout the project.

\section{Authors' Contribution}

None declared.

\section{Financial Disclosure}

None declared.

\section{Funding/Support}

None declared.

\section{References}

1. Pearson RD, Sousa AQ. Clinical spectrum of Leishmaniasis. Clin Infect Dis. 1996;22(1):1-13.

2. WE C. Control of the leishmaniasis. 1990

3. Desjeux P. Leishmaniasis: current situation and new perspectives. Comp Immunol Microbiol Infect Dis. 2004;27(5):305-18.

4. Rassi Y, Oshaghi MA, Azani SM, Abaie MR, Rafizadeh S, Mohebai $\mathrm{M}$, et al. Molecular detection of Leishmania infection due to Leishmania major and Leishmania turanica in the vectors and reservoir host in Iran. Vector Borne Zoonotic Dis. 2011;11(2):145-50.

5. Gramiccia M, Gradoni L. The current status of zoonotic leishmaniases and approaches to disease control. Int J Parasitol. 2005;35(11-12):1169-80.

6. Saeidi Z, Vatandoost H, Akhavan AA, Yaghoobi-Ershadi MR, Rassi Y, Sheikh Z, et al. Baseline susceptibility of a wild strain of Phlebotomus papatasi (Diptera: Psychodidae) to DDT and pyrethroids in an endemic focus of zoonotic cutaneous leishmaniasis in Iran. Pest Manag Sci. 2012;68(5):669-75.

7. Nadim A, Faghih M. The epidemiology of cutaneous leishmaniasis in the Isfahan province of Iran: I. The reservoir II. The human disease. T Roy Soc Trop Med H. 1968;62(4):534-42.

8. Azizi K, Rassi Y, Moemenbellah-Fard MD. PCR-based detection of Leishmania major kDNA within naturally infected Phlebotomus papatasi in southern Iran. Trans $R$ Soc Trop Med Hyg. 2010;104(6):440-2.

9. Yaghoobi-Ershadi MR, Akhavan AA, Mohebali M. Meriones Iibycus and Rhombomys opimus (Rodentia: Gerbillidae) are the main reservoir hosts in a new focus of zoonotic cutaneous leishmaniasis in Iran. T Roy Soc Trop Med H. 1996;90(5):503-4.

10. Rassi Y, Jalali M, Javadian E, Motazedian MH. Confirmation of Meriones libycus (Rodentia: Gerbillidae) as the main reservoir host of zoonotic cutaneous leishmaniasis in Arsanjan, Fars province, south of Iran (1999-2000). Iranian J Publ Health. 2001;30(3 4):143-4.

11. RASI Y, GHASEMI MM, JAVADIAN E, MOTAZEDIAN H, RAFIZADEH S, AGHAIE AFSHAR A, et al. DETERMINATION OF RESERVOIR (S) AND 
VECTOR (S) OF CUTANEOUS LEISHMANIASIS BY NESTED-PCR IN MARVDASHT DISTRICT, FARS PROVINCE, SOUTHERN IRAN. J KERMAN UNIVER MED SCI. 2007;14(2):134-9.

12. Moemenbellah-Fard MD, Kalantari M, Rassi Y, Javadian E. The PCR-based detection of Leishmania major infections in Meriones libycus (Rodentia: Muridae) from southern Iran. Ann Trop Med Parasitol. 2003;97(8):811-6.

13. Rassi Y, Saghafipour A, Abai MR, Oshaghi MA, Rafizadeh S, Mohebail $\mathrm{M}$, et al. Phlebotomus papatasi and Meriones libycus as the vector and reservoir host of cutaneous leishmaniasis in Qomrood District, Qom Province, central Iran. Asian Pac J Trop Med. 2011;4(2):97-100.

14. Pourmohammadi B, Motazedian MH, Kalantari M. Rodent infection with Leishmania in a new focus of human cutaneous leishmaniasis, in northern Iran. Ann Trop Med Parasitol. 2008;102(2):127-33.

15. Mohammadi-Azni S, Rassi Y, Oshaghi MA, Mohebali M, Abai MR, Hajjaran H. Infection of Rhombomys opimus due to Leishmania major at Zoonotic Cutaneous leihmaniasis focus in Damghan District. Iran J Infect Dis Trop Med. 2012;17(56):53-7.

16. Asgari Q, Motazedian MH, Mehrabani D, Oryan A, Hatam GR, Owji SM, et al. Zoonotic cutaneous leishmaniasis in Shiraz, Southern Iran: A molecular, isoenzyme and morphologic approach. J Res Med Sci. 2007;12(1):7-15.

17. Javadian E, Dehestani M, Nadim A, Rassi Y, Tahvildar-bidruni Gh, Seyedi-Rashti MA, Shadmehr A. CONFIRMATION OF TATERA INDICA (RODENTIA: GERBILLDAE) AS THE MAIN RESERVOIR HOST OF ZOONOTIC CUTANEOUS LEISHMANIASIS IN THE WEST OF IRAN. Iranian J Publ Health. 1998;27(1-2):55-60.
18. Kassiri H, Javadian E, Abdigoudarzi M. Natural Leishmania Infection in Meriones hurrianae and Tatera indica (Rodentia : Cricetidae: Gerbillinae) in Sistan - Baluchistan Province, South - Eastern of Iran. Adv Studies Biol. 2011;6(6):247-56.

19. Mehrabani D, Motazedian MH, Oryan A, Asgari Q, Hatam GR, Karamian M. A search for the rodent hosts of Leishmania major in the Larestan region of southern Iran: demonstration of the parasite in Tatera indica and Gerbillus sp., by microscopy, culture and PCR. Ann Trop Med Parasitol. 2007;101(4):315-22.

20. Motazedian MH, Parhizkari M, Mehrabani D, Hatam G, Asgari Q. First detection of Leishmania major in Rattus norvegicus from Fars Province, Southern Iran. Vector Borne Zoonotic Dis. 2010;10(10):969-75.

21. Azizi K, Moemenbellah-Fard MD, Fakoorziba MR, Fekri S. Gerbillus nanus (Rodentia: Muridae): a new reservoir host of Leishmania major. Ann Trop Med Parasitol. 2011;105(6):431-7.

22. Dezfouli SRN, Oshaghi MA, Vatandoost H, Djavadian E, Telmadarei Z, Assmar M. Use of random amplified polymorphic DNA polymerase chain reaction (RAPD-PCR) and ITS2 PCR assays for differentiation of populations and putative sibling species of Anopheles fluviatilis (Diptera: Culicidae) in Iran. Iran J Publ Health. 2002;31(3-4):133-7.

23. Kassiri H, Naddaf S, Mohebali M, Javadian E. Molecular Characterization of Leishmania Infection in Sand flies From Sistan Va Baluchistan Province, Southeastern Iran. Jundishapur J Microbiol. 2011; 5(2):430-1.

24. Chakraborty S, Nameer PO, Molur S. Meriones hurrianae. In: IUCN 2013. IUCN Red List of Threatened Species. Version 2013.1. 2008; . 